\title{
ANALISIS PENGARUH PERUBAHAN PENGGUNAAN LAHAN TERHADAP DEBIT LIMPASAN PADA DAERAH ALIRAN SUNGAI BONDOYUDO KABUPATEN LUMAJANG DENGAN METODE RASIONAL
}

\author{
Akbar Kurniawan', Fransedo Aminata² \\ 1,2,3 Departemen Teknik Geomatika, FTSLK-ITS, Kampus ITS Sukolilo, Surabaya, 60111, Indonesia \\ e-mail: ${ }^{1}$ akbar.geodesy@gmail.com, ${ }^{2}$ fransedoaminata10@gmail.com
}

\begin{abstract}
Abstrak
Banjir merupakan peristiwa meluapnya air sungai dalam jumlah yang besar pada saat musim hujan. Wilayah DAS Bondoyudo adalah salah satu wilayah yang rawan banjir di Kabupaten Lumajang. Penelitian ini menggunakan metode rasional untuk menghitung debit limpasan di setiap wilayah penelitian dengan rumus sebagai berikut, $Q=0,278$.C.I.A. Dari hasil penelitian ini, wilayah yang tergenang banjir berdasarkan metode rasional yaitu Kecamatan Rowokangkung, Jatiroto, dan Kedungjajang. Pada tahun 2002 wilayah Kecamatan Rowokangkung dan Kedungjajang memiliki selisih debit limpasan yang berlebih sebesar $3,65 \mathrm{m3} / \mathrm{s}$ dan 2,23 m3/s. Sementara pada tahun 2013 terjadi peningkatan selisih debit menjadi 3,72 m3/s dan 2,42 m3/s. Kecamatan Jatiroto juga berpotensi banjir pada tahun 2013 dengan selisih debit $0,35 \mathrm{~m} 3 / \mathrm{s}$. Dan pada tahun 2018 selisih debit pada masing-masing Kecamatan Rowokangkung, Kedungjajang, dan Jatiroto adalah $3,74 \mathrm{m3} / \mathrm{s} ; 2,54 \mathrm{m3} / \mathrm{s}$; dan $0,39 \mathrm{~m} 3 / \mathrm{s}$. Besar pengaruh perubahan penggunaan lahan terhadap debit limpasan dihitung berdasarkan rumus persamaan regresi linier ganda dan dihasilkan dari perhitungan koefisien determinasi. Nilai koefisien determinasi dari Kecamatan Rowokangkung, Kedungjajang, dan Jatiroto adalah 92,5\% , $93,1 \%$, dan $92,4 \%$.
\end{abstract}

Kata Kunci: Banjir, Metode Rasional, Debit Limpasan, Regresi Linier Ganda.

\begin{abstract}
Abtract
Floods is an overflowing of a large amount of water on rainy seasons. Bondoyudo watershed is one of the most flood-prone area in Lumajang district. This research use rational method forcalculate the surface runoff in each researchareas. Theformulais: $Q=0,278 \mathrm{CIA}$. From thisresearch, basedonrationalmethod, floodedareasare Rowokangkung sub-district, Jatiroto sub-district, and Kedungjajang sub-district. In 2002, Rowokangkung sub- district and Kedungjajang sub-district had excess runoff discharge as $3,65 \mathrm{~m} 3 / \mathrm{s}$ and 2, $23 \mathrm{m3} / \mathrm{s}$. In 2010, Rowokangkung, Kedungjajang, and Jatiroto sub-district had excess runoffdischarge as $3,72 \mathrm{~m} 3 / \mathrm{s}, 2,42 \mathrm{~m} 3 / \mathrm{s}$, and0,35 m3/s. In 2018, Rowokangkung, Kedungjajang, andJatirotosub-districthadexcessrunoffdischargeas $3,74 \mathrm{~m} 3 / \mathrm{s}, 2,54 \mathrm{~m} 3 / \mathrm{s}$, $0,39 \mathrm{~m} 3 / \mathrm{s}$. The value of the effect of land use change on runoff discharge is calculated based on multiple linear regression and generated from the calculation of the coefficient of determination. The value of determination coefficient for Rowokangkung Subdistric, Kedungjajang Sub-district, and Jatiroto Sub- district are 92.5\%, 93.1\%, and $92.4 \%$.
\end{abstract}

Keywords: Flood, Rational Method, Runoff Discharge, Multiple Linear Regression 


\section{PENDAHULUAN}

Kabupaten Lumajang merupakan salah satu wilayah di Jawa Timur yang sering dilanda bencana banjir. Hal ini karena kondisi hidrologi wilayah Kabupaten Lumajang sendiri yang merupakan bagian hilir dari 6 Daerah Aliran Sungai (DAS), antara lain: DAS Bondoyudo, DAS Glidik, DAS Mujur, DAS Rawaan, serta DAS Rejali. Banjir yang terjadi rata-rata disebabkan oleh meningkatnya debit air pada saat terjadi hujan secara terusmenerus sehingga mengakibatkan air meluap dan terjadi banjir genangan di lingkungan sekitar daerah aliran sungai. Selain disebabkan oleh curah hujan, banjir genangan juga disebabkan oleh perubahan penggunaan lahan di daerah aliran sungai. Kondisi ini dapat menyebabkan terjadinya gangguan terhadap sistem hidrologi. Perubahan kondisi lahan dari waktu ke waktu membuat ancaman terjadinya banjir semakin besar. Hal ini disebabkan oleh beberapa hal, antara lain:

(1) Daya tampung sungai semakin lama semakin kecil akibat pendangkalan.

(2) Fluktuasi debit air antara musim penghujan dengan musim kering semakin tinggi.

(3) Terjadi konversi lahan pertanian dan daerah buffer alami ke lahan non pertanian dengan mengabaikan konservasi sehingga menyebabkan rusaknya daerah tangkapan air (cacthment area). Perubahan penggunaan lahan dari lahan non-terbangun menjadi lahan terbangun akan menyebabkan terjadinya peningkatan aliran permukaan dan semakin sedikitnya air tanah (Butler, 2011).

Bencana banjir genangan dapat diprediksi dengan pendekatan metode rasional (Suripin, 2003). Metode Rasional merupakan metode matematis untuk menghitung debit limpasan permukaan di wilayah sekitar aliran sungai. Parameter-parameter yang diperlukan dalam perhitungan metode rasional ini adalah curah hujan, kemiringan lereng, jenis tanah, dan tutupan lahan.

Pada penelitian sebelumnya yang dilakukan oleh Ishmata (2016) yaitu membahas tentang aplikasi dari citra tandem-X untuk studi potensi genangan dengan metode rasional. Hasil dari penelitian tersebut yaitu wilayah sub-DAS mana yang berpotensi terjadi banjir genangan berdasarkan perhitungan metode rasional. Untuk penelitian kali ini penulis menggunakan citra satelit Landsat Multitemporal untuk mengidentifikasi perubahan penggunaan lahan di setiap tahun penelitian. Analisis yang dilakukan yaitu menghitung debit limpasan di setiap kecamatan dan menghitung selisih terhadap debit sungai. Selain menggunakan metode rasional, penelitian kali ini juga menggunakan metode skoring atau pembobotan untuk mengetahui daerah mana saja yang rawan terhadap bencana banjir di DAS Bondoyudo Kabupaten Lumajang. Hasil peta potensi banjir dengan metode skoring kemudian dibandingkan hasilnya dengan perhitungan debit limpasan metode rasional di setiap wilayah kecamatan.

\section{METODE}

Lokasi penelitian ini berada di wilayah Kabupaten Lumajang, Provinsi Jawa Timur yang secara geografis terletak pada koordinat antara $112^{\circ} 50^{\prime} 00^{\prime \prime} \mathrm{s} / \mathrm{d} 113^{\circ} 22^{\prime} 00^{\prime \prime}$ BT dan $7^{\circ} 52^{\prime} 00^{\prime \prime} \mathrm{s} / \mathrm{d}$ $8^{\circ} 23^{\prime} 00^{\prime \prime}$ LS khususnya wilayah DAS Bondoyudo. DAS Bondoyudo mencakup 12 wilayah Kecamatan yaitu Kecamatan Ranuyoso, Klakah, Kedungjajang, Randuagung, Jatiroto, Rowokangkung, Yosowilangun, Tekung, Lumajang, Sukodono, Gucialit, dan Senduro. Lokasi penelitian bisa dilihat pada gambar 1 dibawah ini.

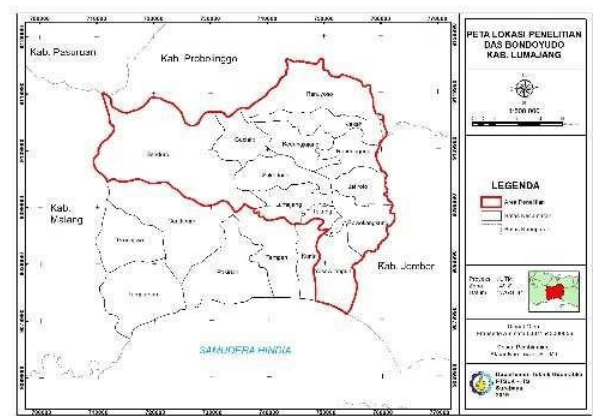

Gambar 1. Lokasi Penelitian

Untuk menganalisis daerah potensi banjir genangan dengan metode rasional pada DAS Bondoyudo diperlukan data-data antara lain Citra Landsat 7 Tahun 2002, Citra Landsat 8 Tahun 2013 dan 2018, Data Curah Hujan Tahun 2002-2018, Data Jenis Tanah, Data DEMNAS Kabupaten Lumajang, dan Data Debit Sungai Eksisting DAS Bondoyudo. 


\section{Diagram Alir Pengolahan Data Metode Rasional}

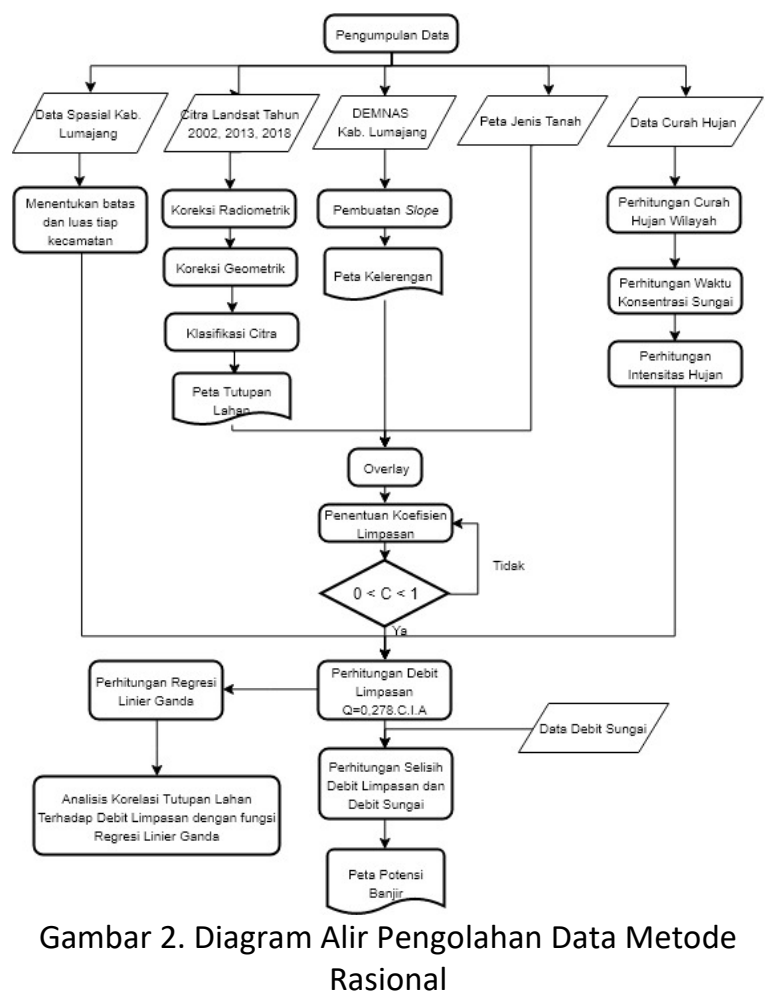

Proses pengolahan data menggunakan metode rasional:

1. Penentuan Luas Wilayah Kecamatan Data spasial Kabupaten Lumajang berupa batas kecamatan yang termasuk dalam DAS Bondoyudo. Kemudian dilakukan perhitungan luas area pada data spasial batas kecamatan, dimana luas wilayah tiap kecamatan ini merupakan salah satu parameter dalam perhitungan debit limpasan menurut metode rasional.

2. Pengolahan Peta Tutupan Lahan Peta tutupan lahan didapatkan dari hasil klasifikasi terbimbing citra Landsat 7 Kabupaten Lumajang Tahun 2002. Dan citra Landsat 8 Kabupaten Lumajang tahun 2013 dan 2018.

3. Pengolahan Peta Kelerengan Peta Kelerengan diturunkan dari data DEMNAS Kabupaten Lumajang. Dari data DEMNAS tersebut kemudian dibuat peta kontur untuk selanjutanya baru diturunkan menjadi peta kelerengan. Peta kelerengan diklasifikasikan sesuai karakteristik DAS menjadi empat kelas lereng, yaitu $0 \%-8 \%, 8 \% 15 \%, 15 \%-25 \%$, 25\%$45 \%$ dan $>45 \%$.
4. Perhitungan Intensitas Hujan Dalam perhitungan intensitas curah hujan, diperlukan beberapa tahap dalam perhitungannya. Tahap awal dilakukan untuk menghitung curah hujan tiap kecamatan. Selanjutnya adalah menghitung waktu konsentrasi aliran (Tc) dengan parameter ketinggian yang didapat dari data DEMNAS. Dan tahap akhir yang dilakukan adalah menghitung intensitas curah hujan dengan rumus Mononobe,

$$
I=[((R 24 / 24) \times(24 / T c))]^{2 / 3}
$$

5. Penentuan Nilai Koefisien Limpasan (C) Nilai koefisien limpasan didapatkan dari nilai hasil overlay peta kelerengan, peta tutupan lahan, dan peta jenis tanah dengan rumus

$$
\mathrm{C}=\mathrm{Ct}+\mathrm{Cs}+\mathrm{Cv} \text {. }
$$

Harga $\mathrm{C}$ memiliki rentang antara $0-1$.

6. Perhitungan Debit Limpasan Perhitungan debit maksimum dilakukan di setiap wilayah kecamatan yang termasuk dalam DAS Bondoyudo dengan menggunakan Metode Rasional dengan 3 parameter utamanya yaitu nilai koefisien limpasan, intensitas curah hujan, dan luas area tiap kecamatan.

7. Perhitungan Selisih Debit Analisis statistik dilakukan dengan melakukan perhitungan selisih antara data debit eksisting dan nilai debit limpasan maksimum hasil perhitungan. Apabila nilai selisih debit bernilai negative, maka debit limpasan lebih besar daripada debit sungai, dan dapat dipastikan daerah tersebut berpotensi banjir genangan ketika musim hujan.

8. Analisis Pengaruh Perubahan Penggunaan Lahan Terhadap Debit Limpasan Analisis dilakukan dengan menghitung luas tutupan lahan tahun 2002, 2013, 2018 dan dikorelasikan dengan debit sungai tahun 2002, 2013, 2018 dengan menggunakan persamaan regresi linier ganda. Dari perhitungan regresi linier ganda akan didapatkan nilai korelasi (R) dan nilai koefisien determinasi (R2). Dimana koefisien determinasi merupakan besaran pengaruh antara perubahan penggunaan lahan terhadap debit limpasan. 


\section{Diagram Alir Pengolahan Data Metode Skoring}

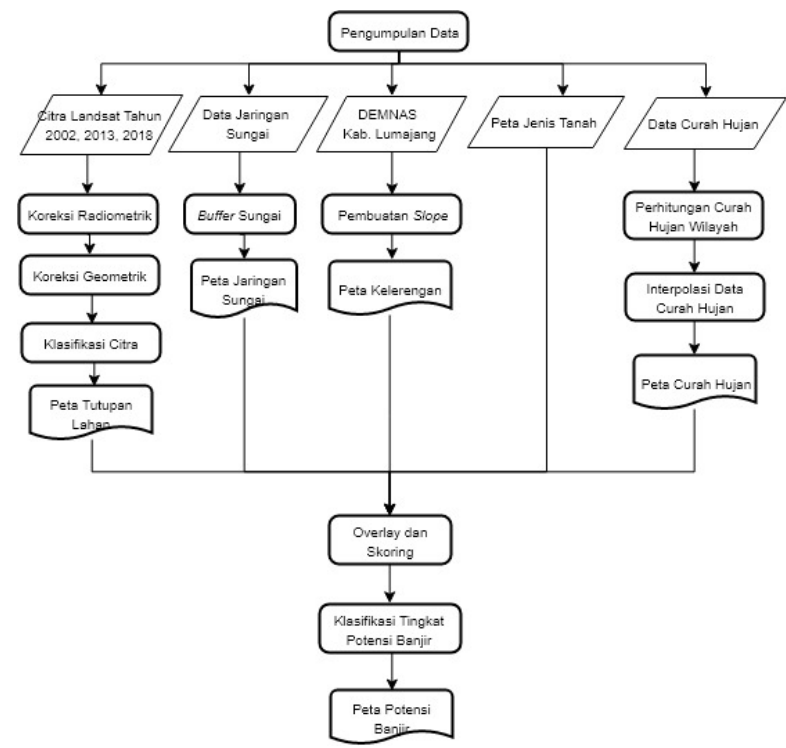

Gambar 3. Diagram Alir Pengolahan Data Metode Skoring

Tabel 1. Nilai Bobot Parameter Banjir

\begin{tabular}{|c|c|c|c|c|}
\hline No & Parameter & Kelas & Skor & Bobot \\
\hline \multirow{6}{*}{1} & \multirow{6}{*}{$\begin{array}{c}\text { Jumlah Curah } \\
\text { Hujan }\end{array}$} & $<1000 \mathrm{~mm} /$ tahun & 1 & \multirow{6}{*}{$30 \%$} \\
\hline & & $1000-1500 \mathrm{~mm} /$ tahun & 2 & \\
\hline & & $1500-2000 \mathrm{~mm} /$ tahun & 3 & \\
\hline & & $2000-2500 \mathrm{~mm} /$ tahun & 4 & \\
\hline & & $>2500 \mathrm{~mm} /$ tahun & 5 & \\
\hline & & Hutan & 1 & \\
\hline \multirow{3}{*}{2} & \multirow{3}{*}{ Tutupan Lahan } & Vegetasi & 2 & \multirow{3}{*}{$20 \%$} \\
\hline & & Kebun & 3 & \\
\hline & & Sawah & 4 & \\
\hline \multirow{5}{*}{3} & \multirow{5}{*}{$\begin{array}{c}\text { Kemiringan Ler } \\
\text { eng }\end{array}$} & Permukiman & 5 & \multirow{5}{*}{$25 \%$} \\
\hline & & $>45 \%$ & 1 & \\
\hline & & $25-45 \%$ & 2 & \\
\hline & & $15-25 \%$ & 3 & \\
\hline & & $8-15 \%$ & 4 & \\
\hline \multirow{4}{*}{4} & \multirow{4}{*}{ Tekstur Tanah } & $0-8 \%$ & 5 & \multirow{4}{*}{$15 \%$} \\
\hline & & Kasar & 1 & \\
\hline & & Sedang & 3 & \\
\hline & & Halus & 5 & \\
\hline \multirow{3}{*}{5} & & $>100 \mathrm{~m}$ & 1 & \multirow{3}{*}{$10 \%$} \\
\hline & Buffer Sungai & $50-100 \mathrm{~m}$ & 3 & \\
\hline & & $0-50 \mathrm{~m}$ & 5 & \\
\hline
\end{tabular}

Analisis Potensi Banjir menggunakan metode skoring (pembobotan) didasarkan pada 5 parameter penyebab bencana banjir yaitu tutupan lahan, buffer sungai, kemiringan lereng, jenis tanah, dan curah hujan. Proses ini dilakukan dengan cara memberikan nilai pada setiap parameter penyebab banjir. Kemudian, masingmasing parameter tersebut ditampalkan (overlay) sehingga dihasilkan data spasial baru berupa daerah rawan banjir. Analisa daerah potensi bencana didasarkan pada nilai total skor dari masing-masing area. Area yang memiliki total skor atau nilai paling tinggi merupakan area yang rawan bencana banjir. Penentuan bobot dan skor beracuan pada contoh tabel skoring yang terdapat pada tinjauan pustaka namun dengan modifikasi untuk penyesuaian dengan wilayah Kabupaten Lumajang. Berikut ini adalah Tabel yang memuat skor dan bobot dari masing-masing parameter penyebab banjir.

\section{HASIL DAN PEMBAHASAN}

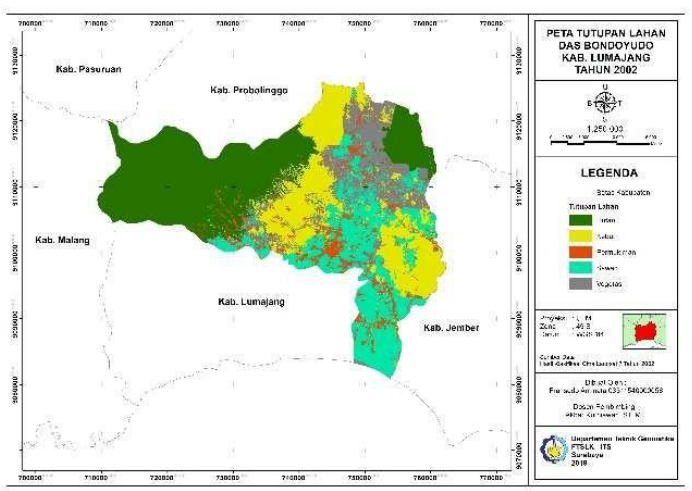

Gambar 4. Peta Tutupan Lahan Tahun 2002

\begin{tabular}{cccccc}
\multicolumn{5}{c}{ Tabel 2. Luas Tutupan Lahan Tahun 2002 } \\
\cline { 2 - 6 } Kecamatan & \multicolumn{5}{c}{ Luas $\left(\mathrm{km}^{2}\right)$} \\
\cline { 2 - 6 } & Hutan & Kebun & $\begin{array}{c}\text { Permuki } \\
\text { man }\end{array}$ & Sawah & Vegetasi \\
\hline Senduro & 178,16 & 15,43 & 5,82 & 6,91 & 14,38 \\
Gucialit & 48,56 & 9,69 & 1,88 & 0,55 & 4,7 \\
Yosowilangun & 1,24 & 7,44 & 11,39 & 58,63 & 8,38 \\
Rowokangkung & 0,27 & 54,44 & 2,36 & 12,59 & 6,13 \\
Tekung & 0,00 & 2,31 & 3,16 & 10,51 & 3,16 \\
Lumajang & 0,29 & 11,43 & 13,85 & 30,61 & 4,3 \\
Sukodono & 1,94 & 35,88 & 5,29 & 17,67 & 12,05 \\
Jatiroto & 0,4 & 22,63 & 5,83 & 17,21 & 3,78 \\
Randuagung & 2,64 & 9,13 & 5,98 & 12,25 & 26,58 \\
Kedungjajang & 8,74 & 24,49 & 7,52 & 11,92 & 16,84 \\
Klakah & 31,88 & 1,30 & 7,30 & 10,02 & 19,25 \\
Ranuyoso & 46,57 & 54,12 & 2,67 & 3,19 & 36,16 \\
TOTAL & 320,69 & 248,29 & 73,05 & 192,06 & 155,71 \\
\hline
\end{tabular}

Peta Penggunaan Lahan Penggunaan lahan merupakan salah satu parameter dalam perhitungan potensi genangan menurut metode rasional. Hasil klasifikasi penggunaan lahan Kabupaten Lumajang dibagi menjadi beberapa kelas penggunaan lahan antara lain permukiman, perkebunan, sawah, vegetasi, dan hutan. Gambar 4, 5, 6 serta Tabel 2, 3, 4 merupakan peta dan tabel perhitungan luas tiap kelas tutupan lahan tahun 
2002, 2013, dan 2018.

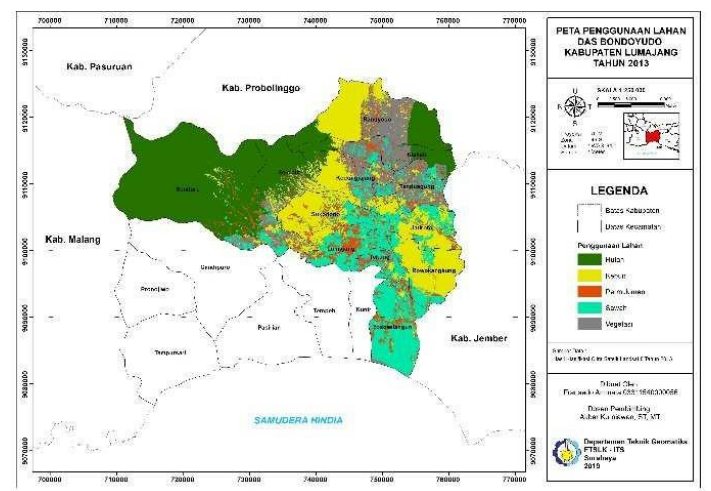

Gambar 5. Peta Tutupan Lahan Tahun 2013

\begin{tabular}{cccccc}
\multicolumn{5}{c}{ Tabel 3. Luas Tutupan Lahan Tahun 2013 } \\
\hline \multirow{5}{*}{ Kecamatan } & Hutan & Kebun & $\begin{array}{c}\text { Permuki } \\
\text { man }\end{array}$ & Sawah & Vegetasi \\
\cline { 2 - 6 } & 176,83 & 17,28 & 6,11 & 4,58 & 15,91 \\
Senduro & 48,18 & 8,95 & 2,04 & 1,18 & 5,03 \\
Gucialit & 0,57 & 8,37 & 12,19 & 58,22 & 7,74 \\
Yosowilangun & 0,19 & 53,88 & 3,17 & 13,14 & 5,42 \\
Rowokangkung & 0,00 & 1,76 & 3,51 & 10,85 & 3,02 \\
Tekung & 0,25 & 10,66 & 14,90 & 30,26 & 4,41 \\
Lumajang & 1,56 & 35,36 & 6,59 & 16,93 & 12,40 \\
Sukodono & 0,21 & 22,21 & 6,63 & 16,83 & 3,97 \\
Jatiroto & 1,95 & 9,94 & 6,74 & 12,21 & 25,74 \\
Randuagung & 8,32 & 24,61 & 8,67 & 11,34 & 16,57 \\
Kedungjajang & 31,05 & 1,99 & 8,11 & 9,06 & 19,55 \\
Klakah & 44,06 & 53,25 & 4,710 & 2,24 & 38,42 \\
Ranuyoso & 313,17 & 248,27 & 83,36 & 186,85 & 158,17 \\
TOTAL & & & & & \\
\hline
\end{tabular}

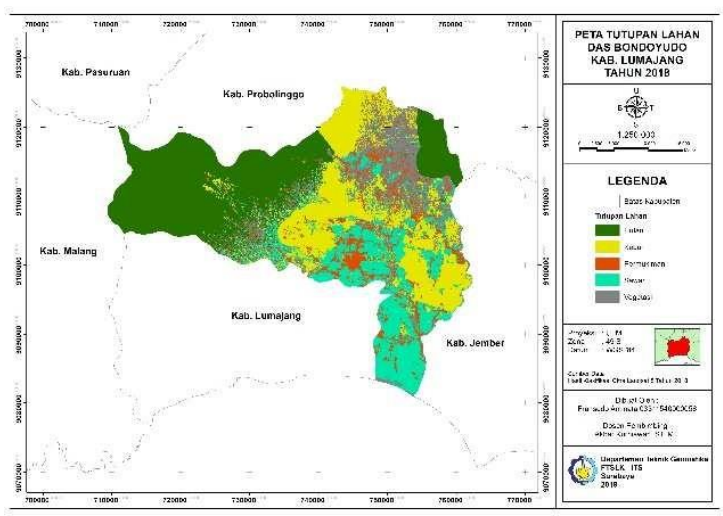

Gambar 6. Peta Tutupan Lahan Tahun 2018

Tabel 4. Luas Tutupan Lahan Tahun 2018

\begin{tabular}{cccccc}
\hline \multirow{2}{*}{ Kecamatan } & \multicolumn{5}{c}{ Luas $\left(\mathrm{km}^{2}\right)$} \\
\cline { 2 - 6 } & Hutan & Kebun & $\begin{array}{c}\text { Permu } \\
\text { kiman }\end{array}$ & Sawah & Vegetasi \\
\hline Senduro & 174,07 & 20,01 & 6,80 & 2,45 & 16,88 \\
Gucialit & 47,58 & 8,32 & 2,39 & 1,69 & 5,40 \\
Yosowilangun & 0,20 & 8,62 & 12,73 & 57,98 & 7,56 \\
Rowokangkung & 0,13 & 53,50 & 3,52 & 13,46 & 5,17
\end{tabular}

\begin{tabular}{cccccc} 
Tekung & 0,01 & 1,68 & 3,55 & 10,97 & 2,93 \\
Lumajang & 0,28 & 10,10 & 16,60 & 28,72 & 4,79 \\
Sukodono & 1,42 & 35,29 & 7,13 & 16,44 & 12,55 \\
Jatiroto & 0,19 & 22,05 & 7,01 & 16,36 & 4,23 \\
Randuagung & 1,86 & 10,43 & 7,08 & 11,71 & 25,50 \\
Kedungjajang & 7,91 & 24,99 & 9,24 & 11,07 & 16,31 \\
Klakah & 30,65 & 2,35 & 8,50 & 8,36 & 19,90 \\
Ranuyoso & 42,64 & 52,45 & 5,47 & 1,54 & 40,61 \\
TOTAL & 306,92 & 249,79 & 90,01 & 180,74 & 161,84 \\
\hline
\end{tabular}

\section{Peta Jaringan Sungai}

Data jaringan sungai diperoleh dari Dinas PU Sumber Daya Air Lumajang. Dari hasil pengolahan dan analisa dapat diketahui wilayah sungai yang sering meluap dan mengakibatkan banjir genangan saat musim hujan yaitu Sungai Jatiroto yang melewati Kecamatan Jatiroto, Rowokangkung, dan Randuagung. Sungai yang kedua yaitu Sungai Grobogan yang melewati Kecamatan Kedungjajang dan Klakah. Berikut merupakan peta sungai yang sering terjadi banjir di DAS Bondoyudo.

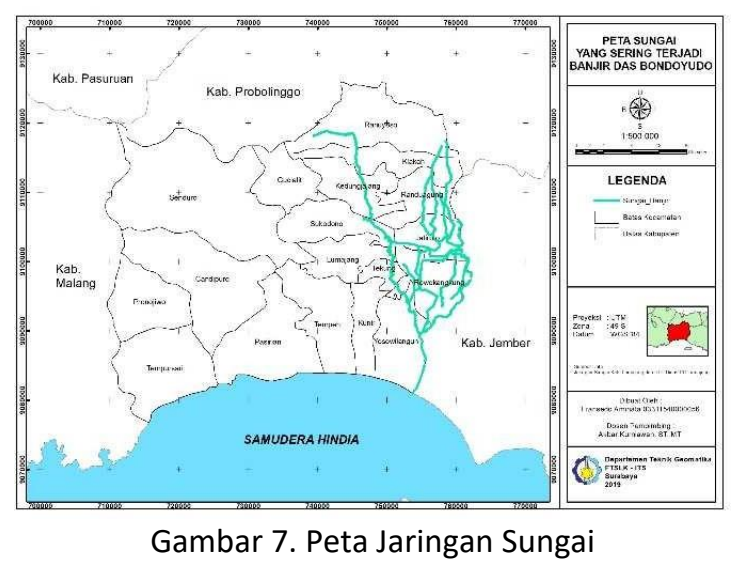

\section{Peta Jenis Tanah}

Jenis tanah merupakan salah satu faktor penyebab banjir genangan. Dimana jenis tanah berpengaruh terhadap proses infiltrasi air hujan ke dalam tanah. Semakin halus tekstur tanah maka tanah semakin resisten dan tidak menyimpan air melainkan mengalirkannya sehingga menjadi limpasan permukaan dan peka terhadap erosi.

\begin{tabular}{lllc}
\multicolumn{4}{c}{ Tabel 5. Jenis Tanah } \\
\hline No & Jenis Tanah & Tekstur Tanah & Luas $\left(\mathrm{km}^{2}\right)$ \\
\hline 1 & Andosol & Pasir & 222,43 \\
2 & Litosol & Lapisan Batu & 254,97 \\
3 & Regosol & Lempung & 362,09 \\
4 & Mediteran & Berpasir & \\
5 & Alluvial & Lanau & 126,24 \\
& & Pasir & 22,66 \\
\hline
\end{tabular}




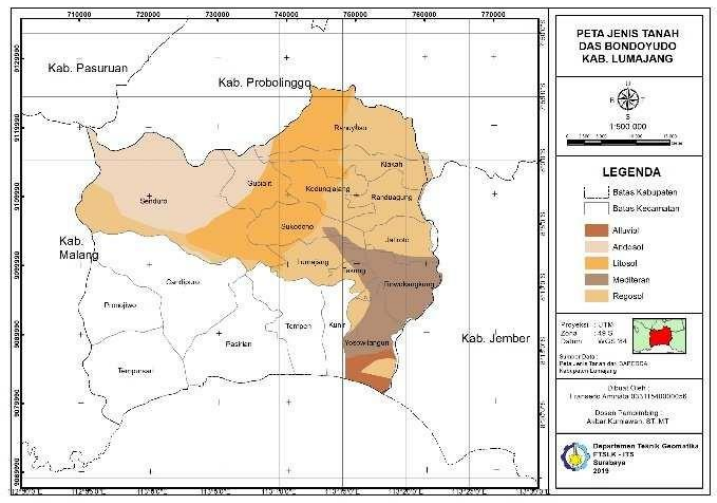

Gambar 8. Peta Jenis Tanah

Tanah dengan tekstur berlapis batubatuan memiliki tekstur tanah yang keras, sehingga air hujan yang jatuh pada wilayah tersebut akan langsung menjadi aliran limpasan permukaan. Akan tetapi, jenis tanah seperti ini biasanya ditemukan di daerah dataran tinggi sehingga air hujan tidak akan terjebak dan menimbulkan genangan.

Jenis tanah yang berpotensi menyebabkan banjir genangan adalah tanah dengan tekstur lanau yang memiliki koefisien sebesar 0,16. Tekstur tanah lanau sulit ditembus oleh air karena memiliki ukuran butiran yang sangat kecil dan halus. Tanah bertekstur lanau banyak terdapat pada Kecamatan Rowokangkung, Kecamatan Jatiroto, dan Kecamatan Yosowilangun, sehingga kecamatan-kecamatan tersebut berpotensi terjadi banjir genangan.

\section{Peta Kelerengan}

Kondisi Topografi atau kelerengan suatu daerah mempengaruhi kecepatan dan volume limpasan permukaan ketika terjadi hujan di wilayah tersebut. Semakin curam tingkat kelerengan maka kecepatan aliran permukaan semakin besar. Semakin datar tingkat kelerengan maka kecepatan aliran permukaan juga semakin kecil (Ishmata, 2016). Hal ini berarti bahwa air hujan akan semakin lama terjebak pada wilayah datar tersebut dan kemungkinan terjadi banjir genangan semakin besar.

Kemiringan lereng pada DAS Bondoyudo Kabupaten Lumajang didominasi oleh wilayah yang datar, yaitu pada wilayah kecamatan Rowokangkung, Jatiroto, Yosowilangun, Tekung, Lumajang, Sukodono, dan kedungjajang, sehingga wilayah-wilayah tersebut memiliki potensi banjir genangan yang lebih tinggi dibandingkan dengan wilayah lain.

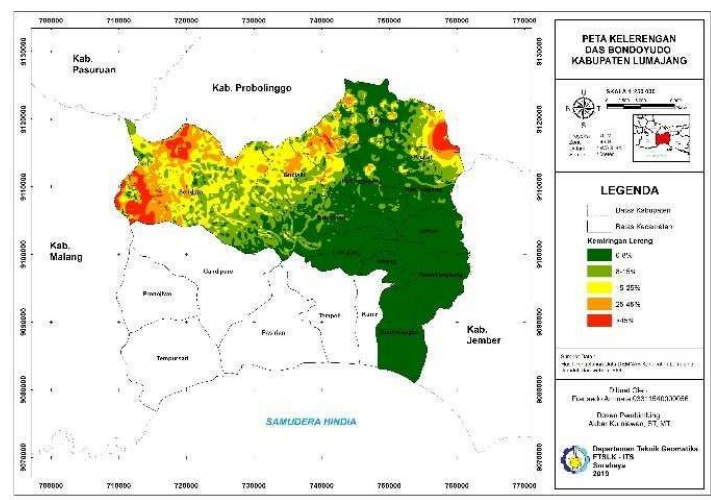

Gambar 9. Peta Kelerengan

\begin{tabular}{cccc}
\multicolumn{4}{c}{ Tabel 6. Kemiringan Lereng } \\
\hline No & $\begin{array}{c}\text { Kemiringan } \\
\text { Lereng }\end{array}$ & Deskripsi & $\begin{array}{c}\text { Luas } \\
\left(\mathrm{km}^{2}\right)\end{array}$ \\
\hline 1 & $0-8 \%$ & Datar & 529,77 \\
2 & $8-15 \%$ & Landai & 168,62 \\
3 & $15-25 \%$ & Agak Curam & 173,85 \\
4 & $25-45 \%$ & Curam & 76,28 \\
5 & $>45 \%$ & Sangat Curam & 39,87 \\
\multicolumn{3}{c}{ TOTAL } & 988,39 \\
\hline
\end{tabular}

\section{Nilai Koefisien Limpasan}

Koefisien limpasan adalah persentase jumlah air yang dapat melimpas/mengalir melalui permukaan tanah dari keseluruhan air hujan yang jatuh pada suatu daerah (Suripin, 2003). Nilai koefisien limpasan ditentukan berdasarkan 3 parameter yaitu tutupan lahan, jenis tanah, dan kemiringan lereng. Dengan menggunakan rumus $C$ $=\mathrm{Ct}+\mathrm{Cs}+\mathrm{Cv}$ dihasilkan nilai koefisien limpasan untuk tiap kecamatan seperti Tabel 7.

Dari 3 tahun penelitian tersebut, Kecamatan Jatiroto memiliki koefisien limpasan yang paling besar, diikuti Kecamatan Rowokangkung pada urutan kedua. Dimana pada tahun 2002 Kecamatan Jatiroto memiliki koefisien limpasan 0,530, pada tahun 2013 naik menjadi 0,552, dan pada tahun 2018 juga naik menjadi 0,565. Sementara untuk Kecamatan Rowokangkung pada tahun 2002, 2013, 2018 secara berturut-turut memiliki koefisien limpasan sebesar 0,533, 0,536, dan 0,531.

Dua kecamatan tersebut berada pada dataran rendah dan jenis tanah dengan tekstur lanau serta lempung yang memiliki nilai koefisien limpasan yang cukup besar. Sehingga dua 
kecamatan tersebut memiliki potensi banjir genangan yang besar juga.

Tabel 7. Nilai Koefisien Limpasan

\begin{tabular}{ccccc}
\multicolumn{5}{c}{ Tabel 7. Nilai Koefisien Limpasan } \\
\hline \multirow{2}{*}{ No } & \multirow{2}{*}{ Kecamatan } & \multicolumn{3}{c}{ Koefisien Limpasan (C) } \\
\cline { 3 - 5 } & & 2002 & 2013 & 2018 \\
\hline 1 & Senduro & 0,184 & 0,185 & 0,187 \\
2 & Gucialit & 0,244 & 0,243 & 0,244 \\
3 & Yosowilangun & 0,369 & 0,377 & 0,381 \\
4 & Rowokangkung & 0,533 & 0,536 & 0,537 \\
5 & Tekung & 0,368 & 0,369 & 0,369 \\
6 & Lumajang & 0,419 & 0,427 & 0,429 \\
7 & Sukodono & 0,389 & 0,395 & 0,399 \\
8 & Jatiroto & 0,529 & 0,552 & 0,554 \\
9 & Randuagung & 0,371 & 0,383 & 0,388 \\
10 & Kedungjajang & 0,379 & 0,388 & 0,394 \\
11 & Klakah & 0,283 & 0,283 & 0,296 \\
12 & Ranuyoso & 0,201 & 0,206 & 0,208 \\
\hline
\end{tabular}

\section{Intensitas Hujan}

Intensitas hujan didefinisikan sebagai tren curah hujan per satuan waktu. Dalam hal ini, perlu diketahui curah hujan yang terjadi dalam satu tahun. Perhitungan dilakukan dalam kurun waktu 10 tahun yaitu antara tahun 2009-2018. Untuk mendapatkan intensitas hujan selama waktu konsentrasi, digunakan rumus Mononobe (Loebis, 1992).

\begin{tabular}{ccc} 
No & Tabel 8. Intensitas Hujan \\
\hline 1 & Sendumatan & $\begin{array}{c}\text { Intensitas } \\
\text { Hujan } \\
\text { (mm/jam) }\end{array}$ \\
\hline 2 & Gucialit & 10,51 \\
3 & Yosowilangun & 4,35 \\
4 & Rowokangkung & 11,10 \\
5 & Tekung & 7,08 \\
6 & Lumajang & 7,75 \\
7 & Sukodono & 9,08 \\
8 & Jatiroto & 11,98 \\
9 & Randuagung & 13,52 \\
10 & Kedungjajang & 11,21 \\
11 & Klakah & 10,09 \\
12 & Ranuyoso & 10,33 \\
\hline
\end{tabular}

\section{Debit Limpasan}

Debit limpasan dihitung dari tiga parameter utama yaitu koefisien limpasan, intensitas hujan, dan luas wilayah penelitian. Hasil perhitungan debit maksimum pada setiap wilayah kecamatan disajikan pada tabel berikut:

\begin{tabular}{ccccc}
\multicolumn{4}{c}{ Tabel 9. Debit Limpasan } \\
\hline \multirow{3}{*}{ No } & Kecamatan & \multicolumn{3}{c}{ Debit Limpasan } \\
\cline { 3 - 5 } & & 2002 & 2013 & 2018 \\
\hline 1 & Senduro & 9,41 & 9,61 & 9,67 \\
2 & Gucialit & 4,59 & 4,49 & 4,38 \\
3 & Yosowilangun & 11,06 & 11,53 & 11,63 \\
4 & Rowokangkung & 11,49 & 11,51 & 11,45 \\
5 & Tekung & 1,72 & 1,69 & 1,71 \\
6 & Lumajang & 6,20 & 6,40 & 6,65 \\
7 & Sukodono & 9,27 & 9,32 & 9,72 \\
8 & Jatiroto & 7,51 & 7,57 & 8,00 \\
9 & Randuagung & 4,27 & 4,79 & 5,19 \\
10 & Kedungjajang & 5,52 & 6,05 & 6,41 \\
11 & Klakah & 4,10 & 4,23 & 4,54 \\
12 & Ranuyoso & 4,75 & 4,83 & 4,81 \\
\hline
\end{tabular}

\section{Debit Sungai}

Debit Sungai eksisting merupakan volume air yang mengalir per satuan waktu pada saat musim hujan. Debit sungai eksisting bisa menjadi acuan kapasitas sungai dalam menampung air pada saat musim hujan. Berikut merupakan tabel debit sungai di masing-masing kecamatan.

\begin{tabular}{ccc}
\multicolumn{3}{c}{ Tabel 10. Debit Sungai Eksisting } \\
\hline No & Kecamatan & $\begin{array}{c}\text { Debit } \\
\text { Sungai } \\
\left(\mathrm{m}^{3} / \mathrm{s}\right)\end{array}$ \\
\hline 1 & Senduro & 13,20 \\
2 & Gucialit & 6,25 \\
3 & Yosowilangun & 35,14 \\
4 & Rowokangkung & 8,81 \\
5 & Tekung & 35,14 \\
6 & Lumajang & 35,14 \\
7 & Sukodono & 35,14 \\
8 & Jatiroto & 8,81 \\
9 & Randuagung & 8,81 \\
10 & Kedungjajang & 6,00 \\
11 & Klakah & 6,00 \\
12 & Ranuyoso & 11,00 \\
\hline
\end{tabular}

\section{Selisih Debit Limpasan dan Debit Sungai}

Setelah dilakukan proses perhitungan debit limpasan maksimum di setiap wilayah kecamatan, maka selanjutnya dihitung selisih nilainya dengan data debit eksisting tiap sungai. Nilai debit eksisting dibandingkan dengan nilai debit limpasan yang lewat maka dapat diketahui daerah mana saja yang aman dan daerah mana yang banjir akibat tidak mampu menampung debit limpasan yang lewat pada saat terjadi hujan maksimum pada waktu tertentu. Untuk nilai selisih bertanda negatif mempunyai arti bahwa daerah 
tersebut berpotensi banjir karena debit limpasan yang lebih besar daripada debit eksisting sungai. Berikut merupakan hasil dari perhitungan selisih antara debit limpasan dan debit sungai.

\begin{tabular}{ccccc}
\multicolumn{2}{c}{ Tabel 11. Selisih Debit Limpasan dan Debit Sungai } \\
\hline \multirow{2}{*}{ No } & \multirow{2}{*}{ Kecamatan } & \multicolumn{3}{c}{ Selisih Debit $\left(\mathrm{m}^{3} / \mathrm{s}\right)$} \\
\cline { 3 - 5 } & & 2002 & 2013 & 2018 \\
\hline 1 & Senduro & 1,89 & 1,67 & 1,31 \\
2 & Gucialit & 10,53 & 10,55 & 10,52 \\
3 & Yosowilangun & 31,25 & 31,17 & 31,13 \\
4 & Rowokangkung & $-3,65$ & $-3,72$ & $-3,74$ \\
5 & Tekung & 33,75 & 33,75 & 33,75 \\
6 & Lumajang & 29,67 & 29,67 & 29,63 \\
7 & Sukodono & 27,03 & 26,39 & 26,33 \\
8 & Jatiroto & 0,02 & $-0,35$ & $-0,39$ \\
9 & Randuagung & 0,91 & 0,67 & 0,56 \\
10 & Kedungjajang & $-2,23$ & $-2,42$ & $-2,54$ \\
11 & Klakah & 0,46 & 0,45 & 0,19 \\
12 & Ranuyoso & 2,75 & 2,57 & 2,48 \\
\hline \multicolumn{7}{c}{} \\
\hline
\end{tabular}

\section{Skoring (Pembobotan)}

Tabel 12. Nilai Bobot Peta Potensi Banjir

\begin{tabular}{|c|c|c|c|c|}
\hline No & Parameter & Kelas & Skor & Bobot \\
\hline \multirow{5}{*}{1} & \multirow{5}{*}{$\begin{array}{c}\text { Jumlah Curah } \\
\text { Hujan }\end{array}$} & $<1000 \mathrm{~mm} /$ tahun & 1 & \multirow{5}{*}{$30 \%$} \\
\hline & & $1000-1500 \mathrm{~mm} /$ tahun & 2 & \\
\hline & & $1500-2000 \mathrm{~mm} /$ tahun & 3 & \\
\hline & & 2000-2500 mm/tahun & 4 & \\
\hline & & $>2500 \mathrm{~mm} /$ tahun & 5 & \\
\hline \multirow{5}{*}{2} & \multirow{5}{*}{$\begin{array}{l}\text { Tutupan } \\
\text { Lahan }\end{array}$} & Hutan & 1 & \multirow{5}{*}{$20 \%$} \\
\hline & & Vegetasi & 2 & \\
\hline & & Kebun & 3 & \\
\hline & & Sawah & 4 & \\
\hline & & Permukiman & 5 & \\
\hline \multirow{5}{*}{3} & \multirow{5}{*}{$\begin{array}{l}\text { Kemiringan } \\
\text { Lereng }\end{array}$} & $>45 \%$ & 1 & \multirow{5}{*}{$25 \%$} \\
\hline & & $25-45 \%$ & 2 & \\
\hline & & $15-25 \%$ & 3 & \\
\hline & & $8-15 \%$ & 4 & \\
\hline & & $0-8 \%$ & 5 & \\
\hline \multirow{3}{*}{4} & \multirow{3}{*}{ Tekstur Tanah } & Kasar & 1 & \multirow{3}{*}{$15 \%$} \\
\hline & & Sedang & 3 & \\
\hline & & Halus & 5 & \\
\hline \multirow{3}{*}{5} & \multirow{3}{*}{ Buffer Sungai } & $>100 \mathrm{~m}$ & 1 & \multirow{3}{*}{$10 \%$} \\
\hline & & $50-100 \mathrm{~m}$ & 3 & \\
\hline & & $0-50 \mathrm{~m}$ & 5 & \\
\hline
\end{tabular}

Potensi Banjir Skoring merupakan pemberian nilai terhadap suatu polygon peta untuk memberikan tingkat kedekatan, keterkaitan atau beratnya dampak tertentu pada suatu fenomena secara spasial (Pratomo, 2009). Peta potensi banjir dengan metode skoring digunakan sebagai pembanding hasil perhitungan banjir genangan dengan metode rasional. Tabel 12 memuat skor dan bobot dari masing-masing parameter penyebab banjir.

Peta potensi rawan banjir didapatkan dari hasil overlay peta curah hujan, peta tutupan lahan, peta kemiringan lereng, peta jenis tanah, dan buffer sungai. Potensi banjir dalam penelitian ini dibagi menjadi 3 kelas tingkat potensi yaitu rendah, sedang, dan tinggi.Berikut merupakan peta potensi banjir dengan metode skoring tahun 2002, 2013, 2018.
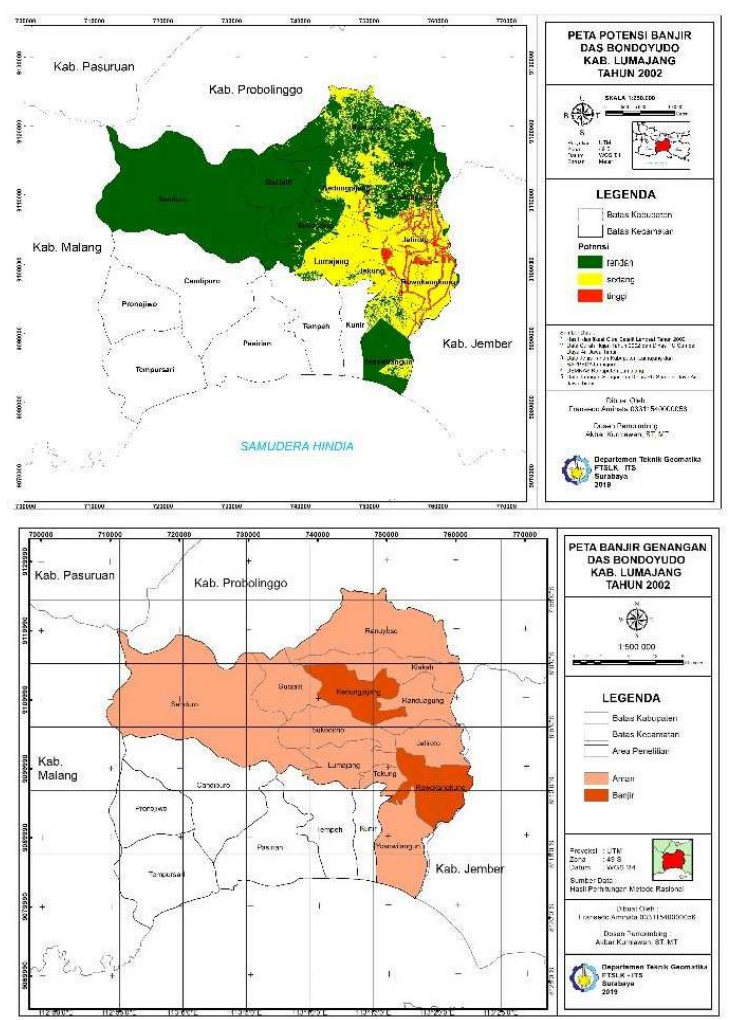

Gambar 10. Perbandingan Hasil Metode Skoring dan Metode Rasional Tahun 2002

Tabel 13. Luas Potensi Banjir Tahun 2002

\begin{tabular}{|c|c|c|c|c|}
\hline No & $\begin{array}{l}\text { Tingkat } \\
\text { Potensi } \\
\text { Banjir }\end{array}$ & $\begin{array}{l}\text { Luas } \\
(\mathrm{km} 2)\end{array}$ & $\begin{array}{l}\text { Prose } \\
\text { ntase } \\
(\%)\end{array}$ & Lokasi \\
\hline 1 & $\begin{array}{l}\text { Potensi } \\
\text { Rendah }\end{array}$ & 675,09 & 66,62 & $\begin{array}{l}\text { Kecamatan Ranuyoso, } \\
\text { Gucialit, Senduro, } \\
\text { Klakah, Randuagung, } \\
\text { Yosowilangun }\end{array}$ \\
\hline 2 & $\begin{array}{l}\text { Potensi } \\
\text { Sedang }\end{array}$ & 288,50 & 31,10 & $\begin{array}{l}\text { Kecamatan Lumajang, } \\
\text { Sukodono, Jatiroto, } \\
\text { Rowokangkung, } \\
\text { Tekung }\end{array}$ \\
\hline 3 & $\begin{array}{c}\text { Potensi } \\
\text { Tinggi }\end{array}$ & 24,80 & 2,28 & $\begin{array}{l}\text { Kecamatan Jatiroto, } \\
\text { Rowokangkung, } \\
\text { Randuagung, } \\
\text { Kedungjajang }\end{array}$ \\
\hline & OTAL & 988,39 & 100 & \\
\hline
\end{tabular}




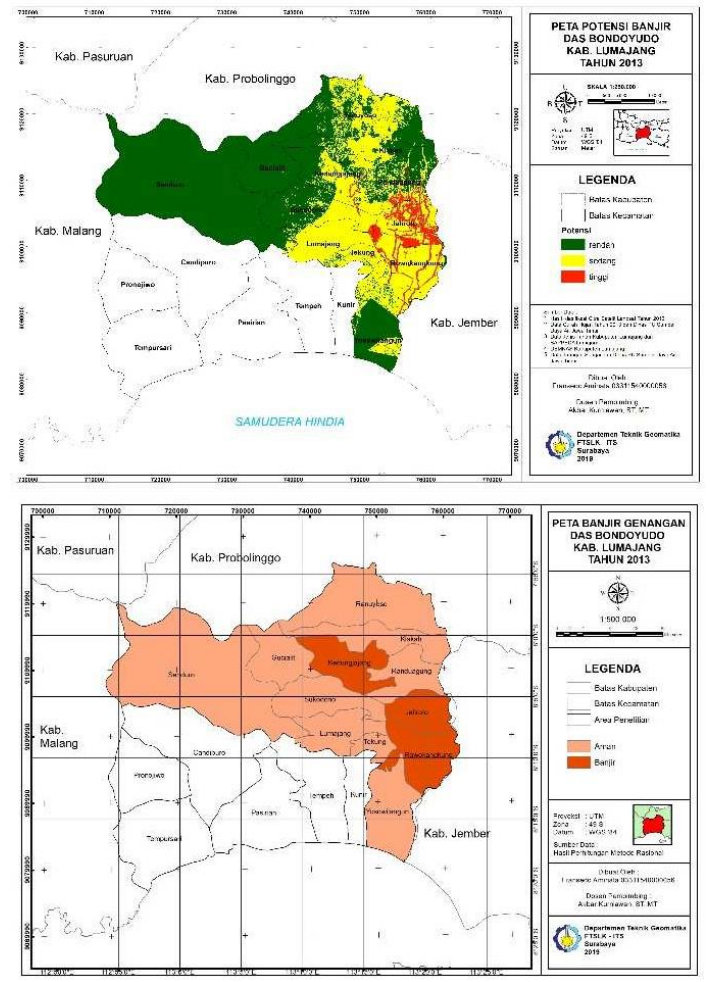

Gambar 11. Perbandingan Hasil Metode Skoring dan Metode Rasional Tahun 2013

Tabel 14. Luas Potensi Banjir Tahun 2013

\begin{tabular}{|c|c|c|c|c|}
\hline No & $\begin{array}{c}\text { Tingkat } \\
\text { Potensi } \\
\text { Banjir }\end{array}$ & $\begin{array}{l}\text { Luas } \\
(\mathrm{km} 2)\end{array}$ & $\begin{array}{c}\text { Prose } \\
\text { ntase } \\
(\%) \\
\end{array}$ & Lokasi \\
\hline 1 & $\begin{array}{l}\text { Potensi } \\
\text { Rendah }\end{array}$ & 664,66 & 65,66 & $\begin{array}{l}\text { Kecamatan Ranuyoso, } \\
\text { Gucialit, Senduro, } \\
\text { Klakah, Randuagung, } \\
\text { Yosowilangun }\end{array}$ \\
\hline 2 & $\begin{array}{l}\text { Potensi } \\
\text { Sedang }\end{array}$ & 287,89 & 31,04 & $\begin{array}{l}\text { Kecamatan Lumajang, } \\
\text { Sukodono, } \\
\text { Kedungjajang, Jatiroto, } \\
\text { Rowokangkung, } \\
\text { Tekung }\end{array}$ \\
\hline 3 & $\begin{array}{l}\text { Potensi } \\
\text { Tinggi }\end{array}$ & 35,84 & 3,29 & $\begin{array}{l}\text { Kecamatan Jatiroto, } \\
\text { Rowokangkung, } \\
\text { Randuagung, } \\
\text { Kedungjajang }\end{array}$ \\
\hline & OTAL & 988,39 & 100 & \\
\hline
\end{tabular}

Tabel 15. Luas Potensi Banjir Tahun 2018

\begin{tabular}{|c|c|c|c|c|}
\hline No & $\begin{array}{l}\text { Tingkat } \\
\text { Potensi } \\
\text { Banjir }\end{array}$ & $\begin{array}{l}\text { Luas } \\
(\mathrm{km} 2)\end{array}$ & $\begin{array}{c}\text { Prose } \\
\text { ntase } \\
(\%)\end{array}$ & Lokasi \\
\hline 1 & $\begin{array}{l}\text { Potensi } \\
\text { Rendah }\end{array}$ & 633,63 & 62,81 & $\begin{array}{l}\text { Kecamatan Ranuyoso, } \\
\text { Gucialit, Senduro, } \\
\text { Klakah, Randuagung, } \\
\text { Yosowilangun }\end{array}$ \\
\hline 2 & $\begin{array}{l}\text { Potensi } \\
\text { Sedang }\end{array}$ & 317,45 & 33,76 & $\begin{array}{l}\text { Kecamatan Lumajang, } \\
\text { Sukodono, } \\
\text { Kedungjajang, Jatiroto, } \\
\text { Rowokangkung, } \\
\text { Tekung }\end{array}$ \\
\hline 3 & $\begin{array}{l}\text { Potensi } \\
\text { Tinggi }\end{array}$ & 37,31 & 3,43 & $\begin{array}{l}\text { Kecamatan Jatiroto, } \\
\text { Rowokangkung, } \\
\text { Randuagung, } \\
\text { Kedungjajang }\end{array}$ \\
\hline & TOTAL & 988,39 & 100 & \\
\hline
\end{tabular}

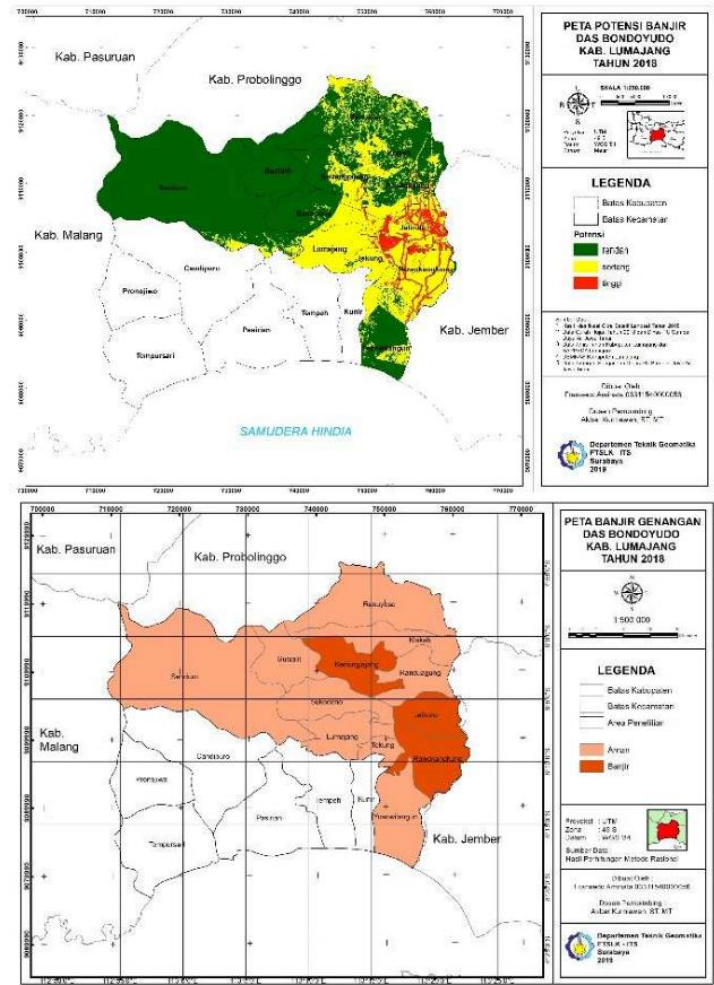

Gambar 12. Perbandingan Hasil Metode Skoring dan Metode Rasional Tahun 2018

\section{Korelasi Perubahan Penggunaan Lahan Terhadap Debit Limpasan}

Analisis Korelasi digunakan untuk mengetahui pengaruh perubahan luas penggunaan lahan terhadap jumlah debit limpasan. Dalam penelitian ini digunakan analisis regresi linier berganda dengan 5 variabel bebas dan 1 variabel terikat. Variabel bebas yang dimaksud yaitu kelas tutupan lahan antaraa lain hutan (X1), kebun (X2), permukiman (X3), sawah (X4), dan vegetasi (X5). Sedangkan untuk variabel terikatnya yaitu debit limpasan hasil perhitungan ( $\mathrm{Y}$ ). Bentuk persamaan dari regresi linier berganda dengan 5 variabel bebas seperti berikut (Chapra, 1996):

$$
Y=b_{0}+b_{1} \cdot X_{1}+b_{2} \cdot X_{2}+b_{3} \cdot X_{3}+b_{4} \cdot X_{4}+b_{5} \cdot X_{5}
$$

Nilai koefisien regresi dari masing-masing variabel ditampilkan pada Tabel 16. Dengan menggunakan rumus persamaan regresi linier berganda maka berdasarkan nilai koefisien pada tabel diatas untuk Kecamatan Rowokangkung persamaannya adalah:

$Y=44,895-0,692 \times 1-0,102 \times 2+0,082 \times 3+$ $0,110 \times 4-0,098 \times 5$ 


\begin{tabular}{|c|c|c|c|c|c|c|}
\hline \multicolumn{7}{|c|}{$\begin{array}{r}\text { Tabel 16. Hasil Perhitungan } \\
\text { Ganda }\end{array}$} \\
\hline \multirow{2}{*}{ Kecamatan } & \multicolumn{6}{|c|}{ Koefisien Regresi } \\
\hline & b0 & $\mathrm{b} 1$ & b2 & b3 & b4 & b5 \\
\hline Senduro & 44,895 & $-0,165$ & 0,430 & 0,184 & $-0,084$ & 0,067 \\
\hline Gucialit & 4,675 & $-0,007$ & $-0,002$ & 0,017 & 0,002 & 0,006 \\
\hline Yosowilangun & 14,390 & $-0,120$ & 0,101 & 0,094 & $-0,192$ & $-0,146$ \\
\hline Rowokangkung & 17,037 & $-0,692$ & $-0,102$ & 0,082 & 0,110 & $-0,098$ \\
\hline Tekung & 1,338 & 0,122 & $-0,005$ & 0,008 & 0,007 & $-0,013$ \\
\hline Lumajang & 5,569 & 0,134 & $-0,029$ & 0,021 & $-0,018$ & 0,087 \\
\hline Sukodono & 14,253 & $-0,329$ & $-0,071$ & 0,071 & 0,210 & $-0,498$ \\
\hline Jatiroto & 28,438 & $-1,954$ & $-0,752$ & 0,366 & $-0,469$ & 0,851 \\
\hline Randuagung & 17,922 & $-0,409$ & 0,270 & 0,315 & $-0,464$ & $-0,311$ \\
\hline Kedungjajang & 10,141 & $-0,377$ & 0,555 & 0,180 & $-0,361$ & $-0,586$ \\
\hline Klakah & 2,662 & $=0,189$ & 0,227 & 0,194 & $=0,154$ & 0,424 \\
\hline Ranuyoso & 10,582 & $-0,026$ & $-0,005$ & 0,010 & $-0,002$ & $-0,008$ \\
\hline
\end{tabular}

Hal ini mengandung pengertian bahwa setiap ada pertambahan luas hutan (X1) sebesar 1 km2 maka jumlah debit limpasan (Y) akan berkurang sebesar 0,692 dengan asumsi bahwa variabel bebas yang lain dari model regresi adalah tetap. Hal yang sama juga terjadi apabila luas kebun (X2) bertambah $1 \mathrm{~km} 2$ maka jumlah debit limpasan berkurang sebesar 0,102 . Untuk variabel permukiman (X3) apabila terjadi pertambahan luas $1 \mathrm{~km} 2$ maka jumlah debit limpasan juga ikut bertambah sebesar 0,082 karena bertanda positif. Untuk variabel sawah (X4) apabila terjadi pertambahan luas $1 \mathrm{~km} 2$ maka jumlah debit limpasan bertambah 0,110. Dan untuk variabel vegetasi (X5) apabila terjadi pertambahan luas 1 km2 maka jumlah debit limpasan akan berkurang sebesar 0,098.

Selanjutnya dilakukan perhitungan koefisien korelasi $(\mathrm{R})$ dan koefisien determinasi (R2) untuk mengetahui hubungan korelasi antara perubahan luas penggunaan lahan dan debit limpasan. Nilai korelasi dihitung berdasarkan rumus berikut:

$$
R_{x 1, x 2 \ldots x i y}=\sqrt{\frac{b_{1} \sum x 1 y+b_{2} \sum x 2 y+\cdots+b_{n} \sum x i y}{\sum y^{2}}}
$$

Hasil perhitungan koefisien korelasi dari setiap wilayah kecamatan penelitian disajikan pada Tabel 17. Dilihat dari Tabel 17, rata-rata setiap kecamatan memiliki hubungan korelasi antara 0,9 s/d 1 dimana nilai tersebut masuk ke dalam kategori korelasi kuat. Jadi dapat diartikan bahwa perubahan luas ke-5 kelas tutupan lahan berpengaruh signifikan terhadap perubahan debit limpasan setiap tahunnya.

\begin{tabular}{ccc}
\multicolumn{3}{c}{ Tabel 17. Nilai Koefisien Korelasi } \\
\hline No & Kecamatan & Koefisien Korelasi \\
\hline 1 & Senduro & 0,959 \\
2 & Gucialit & 0,960 \\
3 & Yosowilangun & 0,968 \\
4 & Rowokangkung & 0,967 \\
5 & Tekung & 0,938 \\
6 & Lumajang & 0,944 \\
7 & Sukodono & 0,966 \\
8 & Jatiroto & 0,962 \\
9 & Randuagung & 0,960 \\
10 & Kedungjajang & 0,965 \\
11 & Klakah & 0,953 \\
12 & Ranuyoso & 0,967 \\
\hline
\end{tabular}

Untuk mengetahui besaran pengaruh dari perubahan luas tutupan lahan terhadap jumlah debit limpasan dapat dihitung dengan rumus koefisien determinasi, yang disajikan pada tabel dibawah ini:

Tabel 18. Nilai Koefisien Determinasi

\begin{tabular}{ccc}
\hline No & Kecamatan & Koefisien Determinasi \\
\hline 1 & Senduro & 0,920 \\
2 & Gucialit & 0,923 \\
3 & Yosowilangun & 0,936 \\
4 & Rowokangkung & 0,935 \\
5 & Tekung & 0,880 \\
6 & Lumajang & 0,891 \\
7 & Sukodono & 0,933 \\
8 & Jatiroto & 0,924 \\
9 & Randuagung & 0,921 \\
10 & Kedungjajang & 0,931 \\
11 & Klakah & 0,908 \\
12 & Ranuyoso & 0,935 \\
\hline
\end{tabular}

Nilai koefisien determinasi menunjukkan besaran pengaruh dari variabel tutupan lahan terhadap jumlah debit limpasan. Sebagai contoh pada Kecamatan yang berpotensi banjir menurut metode rasional yaitu Kecamatan Rowokangkung dan Jatiroto memiliki koefisien determinasi sebesar 0,935 dan 0,924. Dengan dikalikan 100\% maka pengaruh variabel tutupan lahan pada Kecamatan Rowokangkung dan Jatiroto berpengaruh $93,5 \%$ dan $92,4 \%$ terhadap jumlah debit limpasan. Sedangkan 6-7\% dipengaruhi oleh faktor lain seperti curah hujan, jenis tanah, dan kemiringan lereng.

Faktor lain yang mempengaruhi debit limpasan yang pertama yaitu curah hujan. Menurut Sudaryono (2002) hujan berpengaruh terhadap limpasan yang meliputi tipe, lama, intensitas dan sebaran hujan sangat menentukan 
limpasan permukaan yang terjadi di suatu daerah aliran sungai (DAS). Jumlah/volume debit limpasan berkaitan dengan intensitas dan lamanya hujan turun yang terjadi pada DAS yang bersangkutan.

Faktor jenis tanah juga berkontribusi terhadap peningkatan debit limpasan. Jenis tanah yang terdapat pada Kecamatan Rowokangkung dan Jatiroto merupakan tanah dengan tekstur lanau. Dimana tanah bertekstur lanau memiliki koefisien yang cukup tinggi yaitu 0,16 . Tanah lanau memiliki tekstur yang sangat halus sehingga memiliki daya infiltrasi yang rendah, maka tanah semakin resisten dan tidak meyimpan air melainkan mengalirkannya sehingga menjadi limpasan air dan peka terhadap erosi (Arsyad, 2010).

Bentuk topografi suatu daerah (kelerengan) juga berpengaruh pada volume dan debit limpasan permukaan. Kecamatan Rowokangkung dan Jatiroto berada pada tingkat kemiringan lereng yang datar (08\%). Dengan kondisi seperti ini maka air hujan yang turun lebih banyak terjebak dan akan menjadi genangan.

\section{KESIMPULAN}

Kesimpulan dari hasil penelitian ini adalah:

1. Wilayah yang berpotensi banjir berdasarkan perhitungan metode rasional pada tahun 2002 adalah Kecamatan Rowokangkung dan Kecamatan Kedungjajang. Sedangkan pada tahun 2013 wilayah yang berpotensi banjir bertambah satu dari tahun 2002 yaitu Kecamatan Jatiroto. Dan pada tahun 2018 wilayah yang berpotensi banjir yaitu Kecamatan Rowokangkung, Kecamatan Kedungjajang, dan Kecamatan Jatiroto.

2. Pada tahun 2002 wilayah Kecamatan Rowokangkung dan Kecamatan Kedungjajang memiliki kelebihan debit limpasan dengan selisih masing-masing $3,65 \mathrm{m3} / \mathrm{s}$ dan 2,23 $\mathrm{m} 3 / \mathrm{s}$. Sementara pada tahun 2013 terjadi peningkatan selisih debit pada dua kecamatan tersebut menjadi $3,72 \mathrm{~m} 3 / \mathrm{s}$ dan $2,42 \mathrm{~m} 3 / \mathrm{s}$. Kecamatan Jatiroto juga berpotensi banjir pada tahun 2013 dengan selisih debit 0,35 m3/s. Dan pada tahun 2018 selisih debit pada masing-masing Kecamatan Rowokangkung, Kecamatan Kedungjajang, dan Kecamatan Jatiroto adalah $3,74 \mathrm{~m} 3 / \mathrm{s}$; $2,54 \mathrm{~m} 3 / \mathrm{s}$; dan $0,39 \mathrm{~m} 3 / \mathrm{s}$.

3. Besar pengaruh perubahan tutupan lahan terhadap peningkatan debit limpasan untuk Kecamatan Rowokangkung adalah 93,5\%. Kecamatan Kedungjajang sebesar 93,1\%. Dan untuk Kecamatan Jatiroto memiliki memiliki pengaruh sebesar $92,4 \%$.

\section{UCAPAN TERIMA KASIH}

Penulis mengucapkan terima kasih kepada Bapak Akbar Kurniawan ST, MT. selaku dosen pembimbing dalam penelitian ini. Terima kasih atas kesempatan, bimbingan, serta dukungan hingga dapat terselesaikannya penelitian ini. Dan ucapan terima kasih kepada UPT Dinas PU Sumber Daya Air Kabupaten Lumajang yang telah memberikan dukungan berupa data curah hujan dan debit sungai sehingga penelitian ini dapat berjalan dengan lancar.

\section{DAFTAR PUSTAKA}

Arsyad, S. 2010. Konserversi Tanah dan Air. Bogor: IPB Press.

Butler, D. dan Davies, J. W. 2011. Urban Drainage, Third Edition. New York: Taylor and Francis Group.

Chapra, Steven. 1996. Metode Numerik Jilid 1 (Diterjemahkan oleh I Nyoman Susila). Jakarta: Erlangga.

Ishmata, A. 2016. Penggunaan Citra TANDEM-X Untuk Studi Potensi Genangan Dengan Prakiraan Debit Sungai Menggunakan Metode Rasional. Skripsi. Teknik Geomatika, Institut Teknologi Sepuluh Nopember

Loebis, Joerson. 1992. Banjir Rencana Untuk Bangunan Air. Departemen Pekerjaan Umum.

Pratomo. 2009. Analisis Kerentanan Banjir di Daerah Aliran Sungai Sengkarang Kabupaten Pekalongan Provinsi Jawa Tengah dengan Bantuan Sistem Informasi Geografis. Fakultas Geografi Universitas Muhammadiyah. Surakarta

Primayuda A, 2006. Pemetaan Daerah Bahaya dan Resiko Banjir Menggunakan Sistem Informasi Geografis: studi kasus Kabupaten Trenggalek, Jawa Timur. Tugas Akhir. Bogor: Fakultas Pertanian, Institut Pertanian Bogor.

Sudaryono. 2002. Pengelolaan Daerah Aliran Sungai (DAS) Terpadu.Bogor: Angkasa.

Suripin. 2003. Sistem Drainase Perkotaan yang Berkelanjutan. Yogyakarta : Andi. 